\title{
Assessment of Automatic Thoughts in Patients with Depressive Illness at a Tertiary Hospital in Nepal
}

\author{
Mita Rana, ${ }^{1}$ Sabitri Sthapit, ${ }^{2}$ Vidya Dev Sharma ${ }^{1}$ \\ 'Department of Psychiatry and Mental Health, Institute of Medicine (IOM), Kathmandu, Nepal, ${ }^{2}$ Central Department of \\ Psychology, Tribhuvan University (TU), Kirtipur, Nepal.
}

\section{ABSTRACT}

Introduction: Cognitive functions have significant influence on psycho-social and general wellbeing. The quality, content and processing of negative thoughts initiate depressive symptoms; i.e. low mood, decreased self-worth and diminished interest in pleasurable activities. The study assessed the automatic thoughts of patients having depressive illness and evaluated and compared the changes after therapy; i.e. Psychotherapy and pharmacotherapy.

Methods: Diagnosed cases of depressive illness ( $n=135)$, according to ICD-10 and study criteria, attending the out-patient clinic of Department of Psychiatry and Mental Health, Tribhuvan University Teaching Hospital, were included. Beck Depression Inventory was used to screen level of depressive symptoms. Automatic thoughts were assessed by the Automatic Thought Questionnaire-Revised before initiating therapy and after completion of therapy for comparison. Depressive patients received either of the three treatment procedures after randomization of the study sample into three different treatment groups; i.e. Cognitive behavior therapy, pharmacotherapy or combined therapy receiving both cognitive behavior therapy and pharmacotherapy.

Results: Among the total 135 patients, 53 (39.3\%) had moderate, 47 (34.8\%) had severe depressive and $35(25.9 \%)$ had mild depressive symptoms before therapeutic interventions. Negative automatic thoughts were significantly present in depressed patients and reduced after all three interventions. Negative automatic thoughts of hopelessness, anxiety and inability coping were significantly reduced after therapy.

Conclusions: Automatic negative thoughts were significantly correlated with depressive disorder. Combined therapy CBT with pharmacotherapy or CBT alone was found to be more effective in modifying automatic negative thoughts than pharmacotherapy alone, ultimately reducing depressive symptoms to a significant degree.

Keywords: automatic thoughts; cognitive Behavior therapy; pharmacotherapy.

\section{INTRODUCTION}

Depressive illness is a mood (affective) disorder, leading cause of disability and the 4th leading contributor to the global burden of disease, ${ }^{1}$ characterized by relapse, recurrence and chronicity and may be mild, moderate or severe, recurrent (repeated), psychogenic or reactive, psychotic or somatic..$^{2,3}$
Automatic negative thoughts are significantly present in depressive illness. ${ }^{4}$ Guilt or worthlessness; feeling rejected and alone is often present and is often

Correspondence: Dr. Mita Rana, Department of Psychiatry and Mental Health, Institute of Medicine (IOM), Kathmandu, Nepal. Email: ranamita@yahoo.co.uk, Phone: +977-9803003925. 
associated with high maladaptive coping and low social support. ${ }^{3,5}$

Depressive symptoms and negative thoughts can be assessed by structured interviews, checklists, interview-based and self-assessed rating scales and questionnaires. The study objective was to assess the automatic thoughts in depressive illness and to determine changes after therapeutic interventions (i.e. cognitive behavior therapy or combined therapy or pharmacotherapy).

\section{METHODS}

This was a randomized comparative study conducted at the Department of Psychiatry and Mental Health, Tribhuvan University Teaching Hospital. Ethical clearance was taken from the Institutional Review Board (IRB), Institute of Medicine, before initiating the research and the ethical guidelines were well considered. ${ }^{6}$ Among various types of depressive disorders, a purposive sample of 135 cases meeting the inclusion-exclusion criteria of the study; i.e. having first episode of depressive disorder without any psychotic symptoms or suicidal attempts, clinically diagnosed according to ICD-10 (DCR) criteria, ${ }^{7}$ by the consultant psychiatrist were selected and randomly distributed to one of the three intervention groups: CBT only (Group I); Pharmacotherapy only (Group II); CBT and Pharmacotherapy Combined (Group III) consecutively. Patients aged 15years, (targeting late adolescence) and above, who were able to read and write and who gave written consent were included. ${ }^{6}$

Beck Depression Inventory (BDI) is a 21 item selfrated questionnaire that describes common symptoms of depression. It has been translated and validated and popularly utilized in the Nepalese population. ${ }^{8-11}$ The ATQ-R includes 30 negative self-statements theoretically associated with depression and taken from the original version of the ATQ, such as "I hate myself" and "I'm a failure", and 10 self-statements reflecting positive affect theorized to be inversely associated with depression, such as "I'm proud of myself" and "I can accomplish anything"12,13 Subjects rate each item on a 5 -point scale indicating how frequently they have these thoughts ( $1=$ not at all, $5=$ all the time). Scores are typically obtained by summing across the items for the respective positive and negative subscales. The splithalf and retest reliability of the ATQ are acceptable, and its concurrent and convergent validity have been well-established. ${ }^{12,13}$ Inter-correlations with the Beck Depression Inventory and the MMPI -Depression Scale have ranged from moderate to high ( $r=0.45$ to 0.70 ). Hill et al. have reported the empirical investigation of the specificity and sensitivity of the ATQ and Dysfunctional Attitude Scale. ${ }^{14}$

The revised version of the ATQ-R has ten added positive self statements. The whole scale is divided into four main factors: Factor I - Depression/Hopelessness statements; Factor II: Inability coping statements; Factor III: Anxiety and Factor IV: Positive self statements. The scale was translated to the Nepali version by three independent translators; a psychologist, a teacher of English language and a sociologist and then back translated to the English version by other three independent translators of the same professions. Out of the three back translations the scale and items matching the original version of the ATQ-R was considered most valid and their Nepali translation was selected and printed with both the original ATQ-R in English and Nepali script together on the same questionnaire and used for the study.

BDI and ATQ-R were used consecutively to screen level of depressive symptoms and determine automatic negative thoughts at pre- therapy (session one) and post- therapy (session 16) assessment. Therapy duration was up to 16 weeks, with weekly sessions for CBT and for pharmacotherapy: follow-up at 0, 2, 6, 12 and 16 weeks. Fluoxetine (mean dose $20 \mathrm{mg} /$ day) and Amitriptyline (mean dose $150 \mathrm{mg} /$ day) were the antidepressants used in combination with or without benzodiazepines.

The collected data were then statistically and clinically analyzed using SPSS 17.0. 


\section{RESULTS}

\begin{tabular}{|c|c|c|c|c|c|c|}
\hline Characteristics & CBT n (\%) & $\begin{array}{l}\text { Pharma-cothera- } \\
\text { py n }(\%)\end{array}$ & $\begin{array}{l}\text { CBT and Pharmaco- } \\
\text { therapy } n(\%)\end{array}$ & Total n (\%) & $\mathrm{X}^{2}$ & $P$ value \\
\hline \multicolumn{7}{|l|}{ Age } \\
\hline $15-25$ years & $20(44.4)$ & $16(35.6)$ & 22 (48.9) & $58(43.0)$ & & \\
\hline $26-35$ yrs & 15 (33.3) & $17(37.8)$ & $14(31.1)$ & $46(34.1)$ & & \\
\hline $36-45$ yrs & $5(11.1)$ & $5(11.1)$ & $5(11.1)$ & $15(11.1)$ & 3.67 & 0.886 \\
\hline $46-55$ yrs & $2(4.4)$ & $5(11.1)$ & $3(6.7)$ & $10(7.4)$ & $(d f=8)$ & NS \\
\hline $56-65$ yrs & $3(6.7)$ & $2(4.4)$ & $1(2.2)$ & $6(4.4)$ & & \\
\hline \multirow[t]{2}{*}{ Mean age } & & 31.82 & & & & \\
\hline & $30.38(26)$ & (28) & $29.09(26)$ & $30.43(27)$ & & \\
\hline Total n (\%) & 45 (100.0) & 45 (100.0) & $45(100.0)$ & 135 (100.0) & & \\
\hline \multicolumn{7}{|l|}{ Sex } \\
\hline Male & $19(42.2)$ & $24(53.3)$ & $18(40.0)$ & $61(45.2)$ & 1.854 & 0.396 \\
\hline Female & $26(57.8)$ & $21(46.7)$ & $27(60.0 \%)$ & $74(54.8)$ & $(d f=2)$ & NS \\
\hline Total n (\%) & 45 (100.0) & 45 (100.0) & 45 (100.0) & 135 (100.0) & & \\
\hline \multicolumn{7}{|l|}{ Marital status } \\
\hline Single & $23(51.1)$ & $16(35.6)$ & $23(51.1)$ & 62 (45.9) & & \\
\hline Married & 22 (48.9) & $26(57.8)$ & $20(44.4)$ & $68(50.4)$ & 8.404 & 0.21 \\
\hline Separated & - & $1(2.2)$ & $2(4.4)$ & $3(2.2)$ & $(d f=6)$ & NS \\
\hline Divorced & - & $2(4.4)$ & - & $2(1.5 \%)$ & & \\
\hline Total n (\%) & $45(100.0)$ & $45(100.0)$ & $45(100.0)$ & $135(100.0)$ & & \\
\hline
\end{tabular}

NS $=$ Not significant

\begin{tabular}{|c|c|c|c|c|c|c|c|}
\hline \multirow[t]{4}{*}{$\begin{array}{l}\text { Pre- therapy } \\
\text { BDI score }\end{array}$} & Sex & $\begin{array}{l}\text { Normal } \\
(0-9)\end{array}$ & $\begin{array}{l}\text { Mild depression } \\
(10-18)\end{array}$ & $\begin{array}{l}\text { Moderate } \\
\text { Depression (19- } \\
\text { 29) }\end{array}$ & $\begin{array}{l}\text { Severe } \\
\text { Depression } \\
\text { (above 30) }\end{array}$ & $\begin{array}{l}\text { Drop- } \\
\text { outs }\end{array}$ & Total N (\%) \\
\hline & Male n (\%) & - & $16(26.2 \%)$ & $25(41.0 \%)$ & 20 (32.8\%) & - & $61(100.0 \%)$ \\
\hline & Female n (\%) & - & $19(25.7 \%)$ & $28(37.8 \%)$ & 27 (36.5\%) & - & $74(100.0 \%)$ \\
\hline & Total n (\%) & - & 35 (25.9\%) & $53(39.3 \%)$ & 47 (34.8\%) & - & $\begin{array}{l}135 \\
(100.0 \%)\end{array}$ \\
\hline
\end{tabular}

Among total 135 patients, 53 (39.3\%) had moderate, 47 (34.8\%) had severe depressive and 35 (25.9\%) had mild depressive symptoms at pre-therapy assessment (Table 2). 
Rana et al. Automatic Thoughts in Patients with Depressive Illness at a Tertiary Hospital in Nepal

\begin{tabular}{|c|c|c|c|c|c|c|c|c|c|c|}
\hline \multirow[t]{2}{*}{$\begin{array}{l}\text { Intervention } \\
\text { Groups }\end{array}$} & \multicolumn{2}{|c|}{$\begin{array}{l}\text { ATQ-R (Negative } \\
\text { thoughts) }\end{array}$} & \multicolumn{2}{|c|}{$\begin{array}{l}\text { ATQ-R. FI } \\
\text { (Depression/ } \\
\text { Hopelessness) }\end{array}$} & \multicolumn{2}{|c|}{$\begin{array}{l}\text { ATQ-R.FII } \\
\text { (Coping } \\
\text { difficulty) }\end{array}$} & \multicolumn{2}{|c|}{$\begin{array}{l}\text { ATQ-R.FIII } \\
\text { (Anxiety) }\end{array}$} & \multicolumn{2}{|c|}{$\begin{array}{l}\text { ATQ-R. FIV } \\
\text { (Positive } \\
\text { thoughts) }\end{array}$} \\
\hline & Mean & (SD) & Mean & (SD) & Mean & (SD) & Mean & (SD) & Mean & (SD) \\
\hline CBT $(n=45)$ & 86.49 & (22.99) & 67.11 & (18.84) & 6.87 & (1.85) & 12.44 & (4.07) & 24.27 & (9.18) \\
\hline $\begin{array}{l}\text { Pharmaco- } \\
\text { therapy }(n=45)\end{array}$ & 90.76 & $(17.43)$ & 71.11 & $(14.02)$ & 7.22 & $(1.72)$ & 12.64 & (3.56) & 22.18 & (6.15) \\
\hline $\begin{array}{l}\text { CBT and } \\
\text { Pharmaco- } \\
\text { therapy }(n=45)\end{array}$ & 91.96 & (19.13) & 72.67 & $(15.52)$ & 7.18 & $(1.66)$ & 13.24 & (3.36) & 20.64 & 6.121 \\
\hline F - ratio & 0.929 & & 1.399 & & 0.555 & & 0.58 & & 2.815 & \\
\hline $\begin{array}{l}\text { Significance } P \\
\text { value }\end{array}$ & 0.397 & & 0.25 & & 0.575 & & 0.561 & & 0.064 & \\
\hline
\end{tabular}

There was no statistical significant difference in the pretherapy assessment scores of the Automatic thoughts in the three intervention groups (Table 3). However, the findings indicate the Combined Therapy Group had more patients with total negative thoughts as well as depressive thoughts and hopelessness followed by the Pharmacotherapy and CBT group consecutively.

\begin{tabular}{|c|c|c|c|c|c|}
\hline $\begin{array}{l}\text { Measures } \\
\text { and Intervention groups }\end{array}$ & $\begin{array}{l}\text { Pre-therapy scores } \\
\text { Mean(SD) }\end{array}$ & $\begin{array}{l}\text { Post- therapy } \\
\text { scores } \\
\text { Mean(SD) }\end{array}$ & $\begin{array}{l}\text { Mean (SD) } \\
\text { Difference }\end{array}$ & t-test & $\begin{array}{l}\text { Sig. } \\
\text { (2-tailed) }\end{array}$ \\
\hline \multicolumn{6}{|c|}{ Automatic Thought Questionnaire-Revised(ATQ-R) Negative thoughts } \\
\hline CBT $(n=36)$ & $90.47(22.877)$ & $\begin{array}{l}49.47 \\
(16.530)\end{array}$ & $41.00(20.526)$ & $11.985 \dagger$ & 0.000 \\
\hline Pharmacotherapy $(n=30)$ & $92.20(16.973)$ & $\begin{array}{l}60.40 \\
(17.214)\end{array}$ & $31.80(18.077)$ & $9.635 \dagger$ & 0.000 \\
\hline $\begin{array}{l}\text { CBT and Pharmacotherapy } \\
(\mathrm{n}=39)\end{array}$ & $92.85(19.544)$ & $\begin{array}{l}47.08 \\
(13.186)\end{array}$ & $45.77(19.034)$ & $15.017 \dagger$ & 0.000 \\
\hline \multicolumn{6}{|c|}{ Automatic Thought Questionnaire-Revised(ATQ-R) Depression/Hopelessness } \\
\hline $\begin{array}{l}\text { CBT } \\
(n=36)\end{array}$ & $70.56(18.522)$ & $\begin{array}{l}38.19 \\
(13.058)\end{array}$ & $32.36(17.664)$ & $10.992 \dagger$ & 0.000 \\
\hline Pharmacotherapy $(\mathrm{N}=30)$ & $72.00(13.854)$ & $\begin{array}{l}46.37 \\
(15.386)\end{array}$ & $25.63(16.550)$ & $8.483 \dagger$ & 0.000 \\
\hline $\begin{array}{l}\text { CBT and Pharmacotherapy } \\
(\mathrm{n}=39)\end{array}$ & $73.10(15.896)$ & $\begin{array}{l}36.38 \\
(10.093)\end{array}$ & $36.72(15.463)$ & $14.829 \dagger$ & 0.000 \\
\hline \multicolumn{6}{|c|}{ Automatic Thought Questionnaire-Revised(ATQ-R) Inability coping } \\
\hline CBT $(n=36)$ & $7.14(1.693)$ & $4.22(1.623)$ & $2.92(1.461)$ & $11.975 t$ & 0.000 \\
\hline Pharmacotherapy $(\mathrm{N}=30)$ & $7.40(1.632)$ & $5.20(1.562)$ & $2.20(2.107)$ & $5.718 \dagger$ & 0.000 \\
\hline $\begin{array}{l}\text { CBT and Pharmacotherapy } \\
(n=39)\end{array}$ & $7.21(1.657)$ & $3.87(1.490)$ & $3.33(2.192)$ & $9.495 \dagger$ & 0.000 \\
\hline \multicolumn{6}{|c|}{ Automatic Thought Questionnaire-Revised(ATQ-R) Anxiety } \\
\hline $\begin{array}{l}\text { CBT } \\
(n=36)\end{array}$ & $12.75(4.003)$ & $\begin{array}{r}7.06 \\
(2.704)\end{array}$ & $\begin{array}{r}5.69 \\
(3.106)\end{array}$ & $11 \dagger$ & 0.000 \\
\hline Pharmacotherapy $(n=30)$ & $13.13(3.491)$ & $\begin{array}{r}9.77 \\
(6.981)\end{array}$ & $\begin{array}{r}3.37 \\
(8.173)\end{array}$ & $256 *$ & 0.032 \\
\hline
\end{tabular}


Rana et al. Automatic Thoughts in Patients with Depressive Illness at a Tertiary Hospital in Nepal

\begin{tabular}{|c|c|c|c|c|c|}
\hline $\begin{array}{l}\text { CBT and Pharmacotherapy } \\
(\mathrm{n}=39)\end{array}$ & $12.82(3.276)$ & & $\begin{array}{r}6.00 \\
(3.649)\end{array}$ & $10.268 \dagger$ & 0.000 \\
\hline \multicolumn{6}{|c|}{ Automatic Thought Questionnaire-Revised(ATQ-R) Positive self statements } \\
\hline CBT $(n=36)$ & $22.81(7.320)$ & $\begin{array}{r}36.69 \\
(7.155)\end{array}$ & $\begin{array}{r}-13.89 \\
(8.400)\end{array}$ & $-9.921 \dagger$ & 0.000 \\
\hline Pharmacotherapy $(n=30)$ & $22.00(5.936)$ & $\begin{array}{r}29.23 \\
(8.249)\end{array}$ & $-7.23(8.787)$ & $-4.509 \dagger$ & 0.000 \\
\hline $\begin{array}{l}\text { CBT and Pharmacotherapy } \\
(\mathrm{n}=39)\end{array}$ & $20.82(6.244)$ & $\begin{array}{r}36.38 \\
(6.201) \\
\end{array}$ & $\begin{array}{r}-15.56 \\
(7.465) \\
\end{array}$ & $-13.02 \dagger$ & 0.000 \\
\hline
\end{tabular}

Significant at ${ }^{*} P<0.01$ and $+P<0.001$ level

Negative automatic thoughts differed significantly from the pre- therapy scores in all three intervention groups and were statistically significant at $\mathrm{P}<0.001$ level (Table 4).

\begin{tabular}{|c|c|c|c|c|c|}
\hline $\begin{array}{l}\text { Measures } \\
\text { and Intervention groups }\end{array}$ & Gain score (SD) & $\begin{array}{l}\text { Gain } \\
\text { Percentage } \\
(\%)\end{array}$ & $\begin{array}{l}\text { \% difference } \\
\text { (Group III and } \\
\text { II) }\end{array}$ & $\begin{array}{l}\text { \% difference } \\
\text { (Group III and } \\
\text { I) }\end{array}$ & $\begin{array}{l}\text { \% difference } \\
\text { (Group I and } \\
\text { II) }\end{array}$ \\
\hline \multicolumn{6}{|c|}{ Automatic Thought Questionnaire-Revised(ATQ-R) Negative thoughts } \\
\hline CBT $(n=36)$ & $41.00(20.526)$ & 45.31 & & & \\
\hline Pharmacotherapy $(n=30)$ & $31.80(18.077)$ & 34.49 & 14.8 & 3.98 & 10.82 \\
\hline $\begin{array}{l}\text { CBT and Pharmacotherapy } \\
(n=39)\end{array}$ & $45.77(19.034)$ & 49.29 & & & \\
\hline \multicolumn{6}{|c|}{ Automatic Thought Questionnaire-Revised(ATQ-R) Depression/Hopelessness } \\
\hline CBT $(n=36)$ & $32.36(17.664)$ & 45.86 & & & \\
\hline Pharmacotherapy $(\mathrm{N}=30)$ & $25.63(16.550)$ & 35.59 & 14.64 & 4.37 & 10.27 \\
\hline $\begin{array}{l}\text { CBT and Pharmacotherapy } \\
(\mathrm{n}=39)\end{array}$ & $36.72(15.463)$ & 50.23 & & & \\
\hline \multicolumn{6}{|c|}{ Automatic Thought Questionnaire-Revised(ATQ-R) Inability coping } \\
\hline CBT Group I ( $n=36)$ & $2.92(1.461)$ & 40.89 & & & \\
\hline Pharmacotherapy ( $n=30$ ) & $2.20(2.107)$ & 29.72 & 16.46 & 5.29 & 11.17 \\
\hline $\begin{array}{l}\text { CBT and Pharmacotherapy } \\
(n=39)\end{array}$ & $3.33(2.192)$ & 46.18 & & & \\
\hline \multicolumn{6}{|c|}{ Automatic Thought Questionnaire-Revised(ATQ-R) Anxiety } \\
\hline CBT $(n=36)$ & $5.69(3.106)$ & 44.62 & & & \\
\hline Pharmacotherapy $(n=30)$ & $3.37(8.173)$ & 25.66 & 21.14 & 2.18 & 18.96 \\
\hline $\begin{array}{l}\text { CBT and Pharmacotherapy } \\
(n=39)\end{array}$ & $6.00(3.649)$ & 46.8 & & & \\
\hline \multicolumn{6}{|c|}{ Automatic Thought Questionnaire-Revised(ATQ-R) Positive self statements } \\
\hline CBT $(n=36)$ & $-13.89(8.400)$ & 60.89 & & & \\
\hline Pharmacotherapy $(n=30)$ & $-7.23(8.787)$ & 32.86 & 41.87 & 13.84 & 28.03 \\
\hline $\begin{array}{l}\text { CBT and Pharmacotherapy } \\
(n=39)\end{array}$ & $-15.56(7.465)$ & 74.73 & & & \\
\hline
\end{tabular}




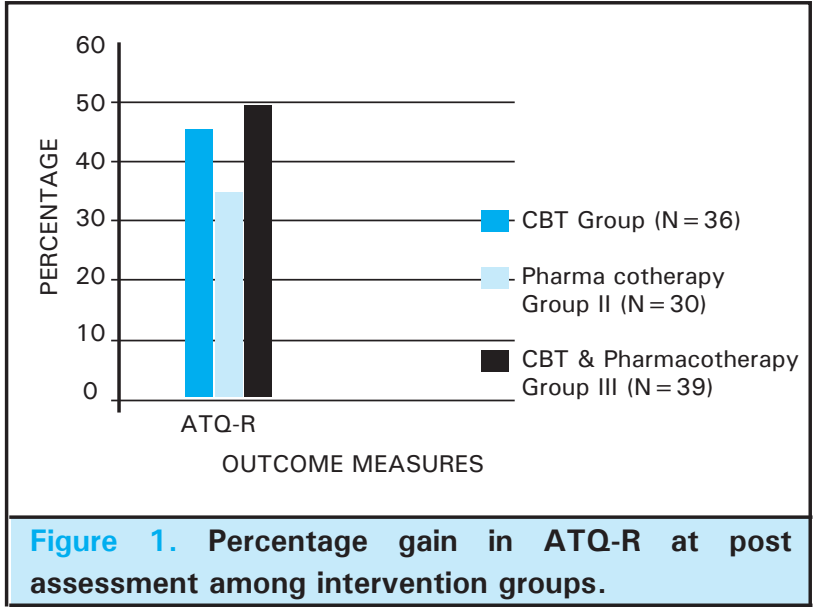

The findings indicate that there were more percentage gains, in the automatic thoughts of the combined therapy group (score $=45.77 ; 49.29 \%$ ) followed by CBT (score $=41 ; 45.31 \%$ ) and Pharmacotherapy (score $=34.49 ; 31.80 \%$ ) interventions. Though there were percentage gains in the automatic thoughts, however there were more percentage gains in the Positive self statements in each of the three therapy interventions; i.e. $74.73 \%$ (score $=-15.56), 60.89 \%$ (score $=-13.89$ ) and $32.86 \%$ (score $=-7.23$ ), the combined therapy group (CBT and pharmacotherapy), the CBT group and the Pharmacotherapy group consecutively (Table 5, Figure 1).

\section{DISCUSSION}

Mental illness is indicated to be more prevalent at a young age in Nepal. This study also has similar findings. Most patients were aged $15-25$ years $(n=58,43.0 \%$ ) and $26-35$ years $(n=46,34.6 \%)$, with mean age of 30.43years. ${ }^{15}$ There were more depressed females ( $n=74,54.8 \%$ ) than males $(n=61,45.2 \%)$ and most of them were either married $(n=68,50.4 \%$ ) or single $(\mathrm{n}=62,45.9 \%){ }^{16}$ There were more single males $(n=41,67.2 \%)$ than females $(n=21,28.37 \%)$ and more married females $(n=49,66.2 \%)$ than males $(n=$ $19,31.1 \%) .{ }^{15-19}$

Negative thoughts were found to be categorically present in patients with depressive illness; developing sense of hopelessness, worthlessness and helplessness and making them feel sad, unhappy, less confident, lacking energy and lacking interest in their daily and pleasurable activities and with sleep and appetite disturbances.

Pre therapy assessment was done on 135 depressive patients; i.e. 45 patients of each therapy groups and there was a drop out of total 30 patients from all three intervention groups; i.e. CBT: 9; Pharmacotherapy: 15 and CBT and Pharmacotherapy: 6. during 16 weeks of therapy. Therefore, the post therapy assessment was carried out on the remaining 105 patients.

Anxious thoughts were found to significantly decrease with age. Patients with significantly higher negative automatic thoughts of hopelessness and inability coping, subjectively rated their depression on a higher level and were found to adhere to treatment for a longer duration.

Cognitive behavior theory views emotional disorder and behavioral problems as secondary to irrational beliefs or faulty information processing. A defining feature of cognitive-behavioral therapy is the proposition that symptoms and dysfunctional behaviors are often cognitively mediated and, hence, improvement can be produced by modifying dysfunctional thinking and beliefs. ${ }^{20}$ Hence assessments of automatic thoughts are essential before starting any kind of therapy, especially psychotherapy.

With the modification and restructuring of negative cognitions in depressive illness, patients experienced positive emotions and contentment, more adaptive and satisfying behavior and most importantly learned skills to identify and overcome their problems. The improvements were determined by post -assessment of automatic thoughts, which indicated decrease in negative thoughts and increased level of positive thoughts.

This study finding supports and emphasizes that cognitive- behavioral intervention, i.e. CBT, when intervened singly is also found to be effective in modifying negative automatic thoughts than pharmacotherapy alone; in reducing depressive symptoms. ${ }^{21}$ However, there is maximum reduction of negative automatic thoughts when pharmacotherapy is combined with CBT. ${ }^{22-24}$ The improvement and change in negative thoughts of hopelessness, anxiety and inability coping in the cognitive domain clearly indicate that the changes taking place by pharmacotherapy alone, was not equivalent to that of dealing with cognitions in a structured manner.

The study had its limitations; the therapist's objective assessment of the severity of the symptoms and conduction of all psychotherapy sessions, i.e. CBT, without independent raters could have introduced subjective biasness and influenced the results. The subjectivity of the patients could be difficult to control as the outcome measures, i.e. ATQ-R, and BDI would rely on their own 
evaluation of their improvement.

\section{CONCLUSIONS}

This study identified the presence of negative automatic thoughts, in depressive illness which is the product of core negative beliefs and cognitive distortions. The study also suggests that enhancing positive cognitive mediation has a significant role in decreasing depressive symptoms which is possible by psychotherapy and Cognitive Behavior Therapy has proven its efficacy in altering distorted cognitions.
Psychological tests that assess and identify negative thoughts prove to be very important and effective both to determine depressive cognitions before treatment as well as to compare improvement after treatment. ${ }^{25}$

\section{ACKNOWLEDGEMENTS}

We acknowledge all the participants for their participation in this study.

\section{Conflict of Interest: None.}

\section{REFERENCES}

1. World Health Organization 2008, The Global Burden of Disease 2004 update. [Full text]

2. Frank E, Prien RF, Jarrett RB, Keller MB, Kupfer DJ, Lavori PW, Rush AJ, Weissman MM. Conceptualization and rationale for consensus definitions of terms in major depressive disorder. Remission, recovery, relapse, and recurrence. Arch Gen Psychiatry. 1991 Sep;48(9):851-5. [ PubMed]

3. International Statistical Classification of Diseases and Related Health Problems 10th Revision (ICD-10) Version for 2010. World Health Organization; 2010. [Full Text]

4. Gable SL, Nezlek JB. Level and instability of day-to-day psychological well-being and risk for depression. J Pers Soc Psychol. 1998 Jan;74(1):129-38. [PubMed]

5. Thorsteinsson EB, Ryan S, Sveinbjornsdottir S. The mediating effects of social support and coping on the stress-depression relationship in rural and urban adolescents. Open Journal of Depression. 2013;2(1):1-6. [Full Text | DOI]

6. Institutional Review Board (2004), Research Department, Institute of Medicine, Tribhuvan University, Kathmandu, Nepal. [ Web link]

7. International Classification of Disease-10 Diagnostic Criteria for Research (ICD-10 DCR). World Health Organization 1992. [Full Text]

8. Beck AT, Ward $\mathrm{CH}$, Mendelson $\mathrm{M}$, et al. An inventory for measuring depression. Archives of General Psychiatry. 1961 June;4:561-71. [Pub Med]

9. Beck AT, Rush AJ, Shaw BF, Emery G. Cognitive therapy of depression. New York: Guilford Press. 1979 [Web link]

10. Kohrt BA, Kunz RD, Koirala NR, Sharma VD, Nepal MK. Validation of the Nepali version of Beck Depression Inventory. The Nepalese Journal of Psychiatry. 2002; 2(4):123-30. [Web link]
11. Ekeblad A, Falkenström F, Andersson G, Vestberg R, Holmqvist R. Randomized Trial of Interpersonal Psychotherapy and Cognitive Behavioral Therapy for Major Depressive Disorder in a Community-Based Psychiatric Outpatient Clinic. Depress Anxiety. 2016 Dec; 33(12):1090-1098. doi: 10.1002/da.22495. Epub 2016 Mar 31. [Pub Med]

12. Hollon SD, Kendall PC. Cognitive self-statements in depression: Development of an automatic thoughts questionnaire. Cognitive Therapy and Research. 1980 December; 4(4): 383-395. [Web link | DOI]

13. Kendall PC, Howard BL, Hays RC. Self-referent speech and psychopathology: The balance of positive and negative thinking. Cognitive Therapy and Research. 1989 December; 13(6): 583-598. [Web link | DOI]

14. Hill CV, Oei TP, Hill MA. An empirical investigation of the specificity and sensitivity of the Automatic Thoughts Questionnaire and Dysfunctional Attitudes Scale. Journal of Psychopathology and Behavioral Assessment. 1989; 11(4): 291-311. [Web Link | DOI]

15. Risal A, Manandhar K, Linde M, et al. Anxiety and depression in Nepal: prevalence, comorbidity and associations.BMC Psychiatry. 2016 April; 16:102. [Full Text | DOI]

16. Patel V, Kirkwood BR, Pednekar S, Pereira B, Barros P, Fernandes J, Datta, J, et al. Gender disadvantage and reproductive health risk factors for common mental disorders in women: a community survey in India. Archives of General Psychiatry. 2006; 63(4):404-413. [ Full Text ]

17. Bebbington PE. The origin of sex differences in depressive disorder: Bridging the gap. International Review of Psychiatry. 1996 July; 8(4):295-332. [DOI]

18. Marco A, Piccinelli GW. Gender differences in depression, Critical review, The British Journal of Psychiatry. 2000 Dec; 177 (6): 486-492. [Full Text |DOI ]

19. Kendler KS, Kessler RC, Neale MC, Heath AC, Eaves LJ. The Prediction of Major Depression in Women: Toward an Integrated Etiologic Model. American Journal of Psychiatry. 1993 Aug; 150(8):1139-48. [ Full Text | DOI] 
20. Dobson KS, Dozois DJA. Historical and philosophical bases of the cognitive-behavioral therapies. In: K.S. Dobson, ed. Handbook of cognitive-behavioral therapies. New York: Guilford Press. 2001; 3rd Ed:3-15 [Full Text]

21. Szentagotai A, David D, Lupu V, Cosman D. Rational emotive behavior therapy versus cognitive therapy versus pharmacotherapy in the treatment of major depressive disorder: Mechanisms of change analysis. Psychotherapy: Theory, Research, Practice, Training. 2008 Dec; 45(4):523-538. [ PubMed | Full Text | DOI]

22. Conte HR, Plutchik R, Wild KV, Karasu TB. Combined psychotherapy and pharmacotherapy for depression. A systematic analysis of the evidence.Arch Gen Psychiatry. 1986 May; 43(5):471-9. [PubMed | Full Text]
23. Hollon SD, DeRubeis RJ, Evans MD, Wiemer MJ, Garvey MJ, Grove WM, Tuason VB. Cognitive therapy and pharmacotherapy for depression. Singly and in combination. Arch Gen Psychiatry. 1992 Oct; 49(10):774-81. [PubMed | Full Text]

24. Jonghe DF, Kool S, Aalst VG, Dekker J, Peen J. Combining psychotherapy and antidepressants in the treatment of depression. J Affect Disord. 2001 May; 64(2-3):217-29. [PubMed | Full Text]

25. Hollon SD, Thase ME, Markowitz JC. Treatment and Prevention of Depression. Psychological science in public interest. 2002 Nov; 3(2):39-77. 